\title{
Desmid algae (Charophyta: Conjugatophyceae) of Ekaterinburg, Middle Urals, Russia
}

\author{
Andrei S. Shakhmatov ${ }^{1 *}$, Evgeniy V. Pavlovskiy ${ }^{1,2} \&$ Alexander G. Paukov $^{1}$ \\ ${ }^{1}$ Ural Federal University, Institute of Natural Sciences and Mathematics, Kuybysheva Street 48, \\ 620000 Ekaterinburg, Russia. *E-mail: shahmatov1992@mail.ru \\ ${ }^{2}$ Institute of Plant and Animal Ecology, Ural Division, Russian Academy of Sciences, 8 Marta Street 202/3, \\ 620144 Ekaterinburg, Russia
}

\begin{abstract}
Species composition of desmid algae and their habitat preferences in water bodies of Ekaterinburg city were studied during the 2013-2017. Thirty-seven species and subspecific taxa which belong to 12 genera and 2 families were identified, of which 17 species are new for the eastern macroslope of the Middle Urals. Canonical correspondence analysis, which was performed to reveal habitat preferences, demonstrates that the majority of analyzed species prefer quarry lakes, ponds and overgrown lake shores, contrary to fens and rivers.
\end{abstract}

Keywords: Middle Urals, biodiversity, new findings, Desmidiales

\section{INTRODUCTION}

Ekaterinburg city is one of the most prominent industrial centers in the Urals that possesses extensive hydrographic network with numerous rivers, lakes, ponds, swamps and fens, where, considering the industrial impact in the studied region, a wide spectrum of environmental conditions has been created, providing a variety of habitats for algae. The territory attracted albeit little attention of algologists and there is a lack of available literature information on algal biodiversity in the region (Butakova \& Stanislavskaya, 2004). The purpose of this work is to provide the results of the long-term biodiversity study of desmid algae and to analyze their habitat preferences.

\section{MATERIAL AND METHODS}

The city of Ekaterinburg is located on the eastern macroslope of the Middle Urals in the southern taiga subzone of the boreal forest zone (Fig. 1), which is characterized by a continental climate with clearly expressed cold and warm periods (average temperature $-16^{\circ} \mathrm{C}$ in January and $+18^{\circ} \mathrm{C}$ in July), and predominance of pine forests in the vegetation (Kulikov et al., 2013).

The samples were collected during the 20132017 by using $40 \mu \mathrm{m}$ mesh-size planktonic net in 22 different-type water bodies, of which 16 are located in an urban area and 9 are in the suburban zone (Table 1). The majority of studied water bodies are exposed to a heavy metal emission, a man-made eutrophication process and a recreational load (Seleznev \& Yarmoshenko, 2014).

The collected material was studied in the laboratory using Levenhuk 320, Micros MC50, Biomed-5 light microscopes and Levenhuk C310 NG, ToupCam U3CMOS18000KPA digital cameras. Cell measurements were made using ToupView v.3.7.1047 and Digimizer v.4.6.1. Species identification was performed using special literature (Kosinskaya, 1960; PalamarMordvintseva, 1982; Coesel \& Meesters, 2007, 2013). Validity of taxa was verified with Algaebase (Guiry \& Guiry, 2018). The establishment of the habitat preferences was performed using Canoco 5.0 for Windows (ter Braak \& Šmilauer, 2012).

\section{LIST OF SPECIES}

The annotated list contains 37 species and subspecific taxa, followed by the finding localities (Loc.), cell measurements (Dim.), and frequency of occurrence ( $\mathrm{s}$ - single finding, $\mathrm{r}$ - rare, c common, a - abundant, $\mathrm{m}$ - mass occurrence). Illustrations are given for every mentioned species. The taxa which are marked by an asterisk $\left({ }^{*}\right)$ are new to the eastern macroslope of the Middle Urals. 

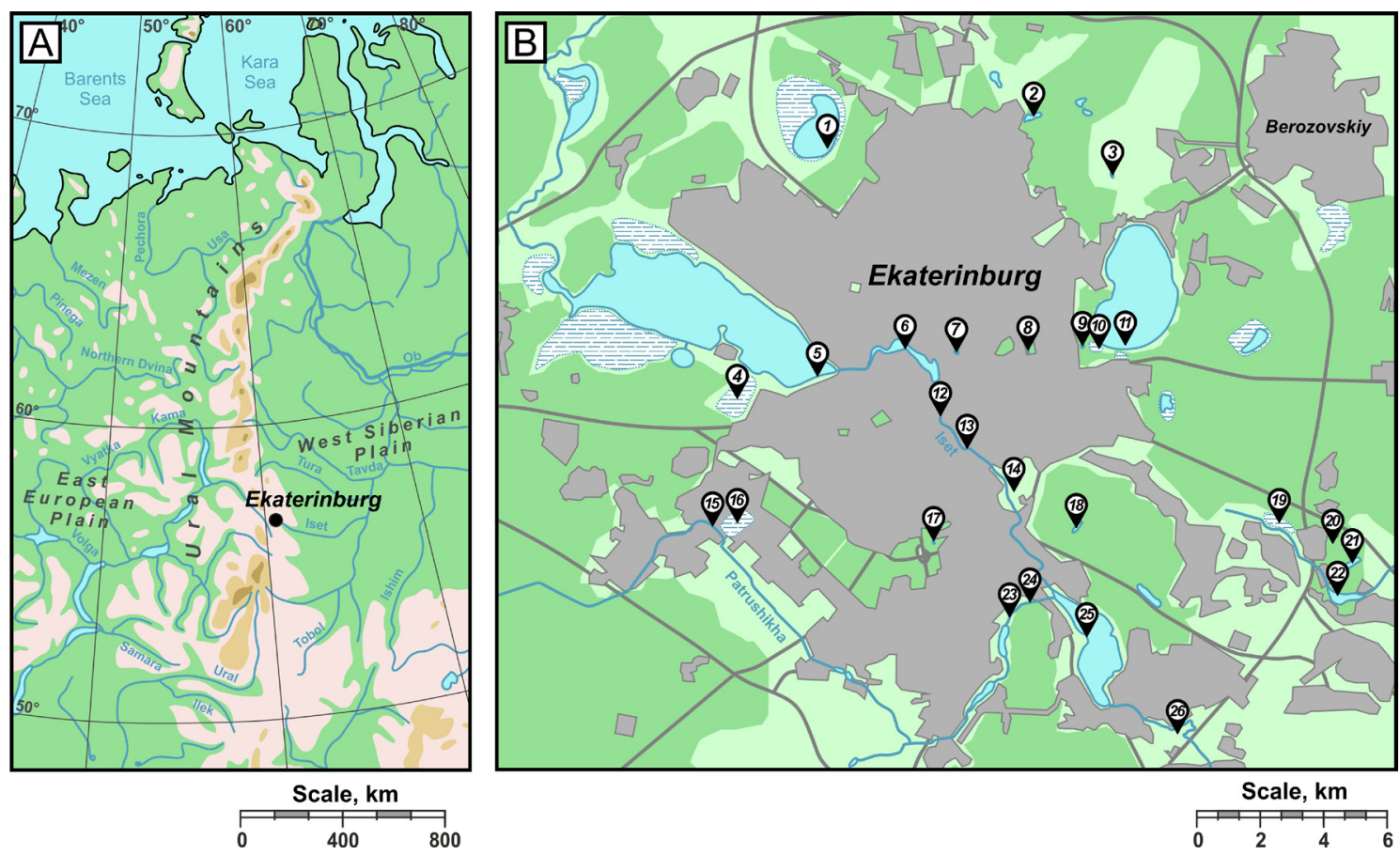

Fig. 1. Location of Ekaterinburg in the Ural Mountains (A) and sampling sites on its territory (B).

Table 1. Characteristics of the sampling sites. The numbering of a site corresponds to the Figure 1, B. Used abbreviations: Lk - lakes, Fn - fens, Q1- quarry lakes, Pd - ponds, Rv - rivers.

\begin{tabular}{|c|c|c|c|}
\hline No & Coordinates & $\begin{array}{l}\text { Water body } \\
\text { type }\end{array}$ & Description \\
\hline 1 & $\begin{array}{l}56.903689^{\circ} \mathrm{N} \\
60.550000^{\circ} \mathrm{E}\end{array}$ & Fn & $\begin{array}{l}\text { Shuvakish lake. Large natural lake-type water body, undergoing the last stages of } \\
\text { transformation into a fen. }\end{array}$ \\
\hline 2 & $\begin{array}{l}56.913213^{\circ} \mathrm{N} \\
60.655570^{\circ} \mathrm{E}\end{array}$ & Ql & Kalinovka pond. Artificial pond with clean sandy banks in the mined-out quarry. \\
\hline 3 & $\begin{array}{l}56.896776^{\circ} \mathrm{N} \\
60.695343^{\circ} \mathrm{E}\end{array}$ & Ql & $\begin{array}{l}\text { Kalinovskiye Razrezy pond. Artificial pond with a pinewood along the banks, } \\
\text { located on the mined-out gold quarry. }\end{array}$ \\
\hline 4 & $\begin{array}{l}56.835418^{\circ} \mathrm{N} \\
60.511745^{\circ} \mathrm{E}\end{array}$ & Fn & Nameless meliorated fen on a bank of the Verkh-Isetskiy pond. \\
\hline 5 & $\begin{array}{l}56.858773^{\circ} \mathrm{N} \\
60.479504^{\circ} \mathrm{E}\end{array}$ & $\mathrm{Rv}$ & Verkh-Isetskiy pond. Large artificial water body on the Iset river. \\
\hline 6 & $\begin{array}{l}56.847187^{\circ} \mathrm{N} \\
60.589237^{\circ} \mathrm{E}\end{array}$ & $\mathrm{Rv}$ & Central city pond. Artificial water body on the Iset river. \\
\hline 7 & $\begin{array}{l}56.846750^{\circ} \mathrm{N} \\
60.613881^{\circ} \mathrm{E}\end{array}$ & $\mathrm{Pd}$ & $\begin{array}{l}\text { Nameless artificial pond in the center of Rastorguyev-Kharitonov mansion park } \\
\text { with clean banks and sedge clumps in the water. }\end{array}$ \\
\hline 8 & $\begin{array}{l}56.847218^{\circ} \mathrm{N} \\
60.649955^{\circ} \mathrm{E}\end{array}$ & $\mathrm{Pd}$ & Nameless artificial pond in the Ekaterinburg Dendrological park. \\
\hline 9 & $\begin{array}{l}56.848604^{\circ} \mathrm{N} \\
60.678205^{\circ} \mathrm{E}\end{array}$ & $\mathrm{Pd}$ & Stariye Karasiki pond. Small water body with sedge hummocks along the banks. \\
\hline 10 & $\begin{array}{l}56.849586^{\circ} \mathrm{N} \\
60.683843^{\circ} \mathrm{E}\end{array}$ & Q1 & Karasiki pond. Shallow artificial water body in an abandoned granite quarry. \\
\hline 11 & $\begin{array}{l}56.848176^{\circ} \mathrm{N} \\
60.697736^{\circ} \mathrm{E}\end{array}$ & $\mathrm{Lk}$ & $\begin{array}{l}\text { Shartash lake. Large natural water body with banks partially covered by pine } \\
\text { forests. }\end{array}$ \\
\hline
\end{tabular}


Table 1 (continued)

\begin{tabular}{|c|c|c|c|}
\hline No & Coordinates & $\begin{array}{l}\text { Water body } \\
\text { type }\end{array}$ & Description \\
\hline 12 & $\begin{array}{l}56.828166^{\circ} \mathrm{N} \\
60.605597^{\circ} \mathrm{E}\end{array}$ & $\mathrm{Rv}$ & Iset river bank near Kuybisheva street. \\
\hline 13 & $\begin{array}{l}56.820555^{\circ} \mathrm{N} \\
60.619748^{\circ} \mathrm{E}\end{array}$ & $\mathrm{Rv}$ & Iset river bank near Belinskogo street. \\
\hline 14 & $\begin{array}{l}56.808208^{\circ} \mathrm{N} \\
60.642415^{\circ} \mathrm{E}\end{array}$ & $\mathrm{Pd}$ & Nameless pond in the "Mayakovsky Central Park". \\
\hline 15 & $\begin{array}{l}56.797907^{\circ} \mathrm{N} \\
60.492862^{\circ} \mathrm{E}\end{array}$ & $\mathrm{Rv}$ & Patrushikha river in the Shirokaya Rechka district. \\
\hline 16 & $\begin{array}{l}56.799464^{\circ} \mathrm{N} \\
60.508968^{\circ} \mathrm{E}\end{array}$ & Fn & Nameless meliorated fen on the Patrushikha river bank. \\
\hline 17 & $\begin{array}{l}56.797499^{\circ} \mathrm{N} \\
60.603020^{\circ} \mathrm{E}\end{array}$ & $\mathrm{Pd}$ & Nameless pond in the Russian Academy of sciences (RAS) botanical garden. \\
\hline 18 & $\begin{array}{l}56.798902^{\circ} \mathrm{N} \\
60.676659^{\circ} \mathrm{E}\end{array}$ & $\mathrm{Pd}$ & Trekhozerka pond in the "Park lesovodov Rossii" Forest Park. \\
\hline 19 & $\begin{array}{l}56.799993^{\circ} \mathrm{N} \\
60.776108^{\circ} \mathrm{E}\end{array}$ & Fn & Nameless turfy fen in the Bukhara-Ural station area. \\
\hline 20 & $\begin{array}{l}56.796158^{\circ} \mathrm{N} \\
60.807511^{\circ} \mathrm{E}\end{array}$ & $\mathrm{Pd}$ & Nameless polluted pond inside the "Lastochka" gardening cooperative. \\
\hline 21 & $\begin{array}{l}56.789788^{\circ} \mathrm{N} \\
60.817146^{\circ} \mathrm{E}\end{array}$ & $\mathrm{Pd}$ & Nameless pond near Maliy Istok water reservoir. \\
\hline 22 & $\begin{array}{l}56.778731^{\circ} \mathrm{N} \\
60.811339^{\circ} \mathrm{E}\end{array}$ & $\mathrm{Rv}$ & Maliy Istok water reservoir located on the Istok river. \\
\hline 23 & $\begin{array}{l}56.775016^{\circ} \mathrm{N} \\
60.639665^{\circ} \mathrm{E}\end{array}$ & $\mathrm{Pd}$ & Patrushikhinskiy pond. Artificial water body on the Patrushikha river. \\
\hline 24 & $\begin{array}{l}56.777978^{\circ} \mathrm{N} \\
60.647491^{\circ} \mathrm{E}\end{array}$ & $\mathrm{Rv}$ & Patrushikha river near the confluence with Iset river. \\
\hline 25 & $\begin{array}{l}56.766939^{\circ} \mathrm{N} \\
60.681233^{\circ} \mathrm{E}\end{array}$ & $\mathrm{Rv}$ & Nizhne-Isetskiy water reservoir located on the Iset river. \\
\hline 26 & $\begin{array}{l}56.740866^{\circ} \mathrm{N} \\
60.726048^{\circ} \mathrm{E}\end{array}$ & $\mathrm{Pd}$ & Artificial pond left after an attempt of straightening of a canal of Iset river. \\
\hline
\end{tabular}

Family: Closteriaceae Bessey, 1907

Closterium acerosum Ehrenberg ex Ralfs, 1848 (Fig. 2, 1-2) - Loc.: 7a, 11r, 19c. Dim.: 471.5$502.8 \mu \mathrm{m}$ length and $50.1-71.2 \mathrm{~mm}$ wide.

CLOSTERIUM LIMNETICUM Lemmermann, 1899 (Fig. 2, 3-4) - Loc.: 2s, 13s, 16s. Dim.: 166.2$270.1 \mu \mathrm{m}$ length and 6.9-10.3 $\mu \mathrm{m}$ wide.

Closterium MONILIFERUm Ehrenberg ex Ralfs, 1848 (Fig. 2, 5) - Loc.: 4a, 6a, 8r, 15a, 19a. Dim.: 250.7-305.1 $\mu \mathrm{m}$ length and 33.8-52.6 $\mu \mathrm{m}$ wide.

Closterium parvulum Nägeli, 1849 (Fig. 2, 6) - Loc.: 4c, 9r, 10a. Dim.: 113.8-136.9 $\mu \mathrm{m}$ length and $10-16.8 \mu \mathrm{m}$ wide.

Closterium TURGIDUM Ehrenberg ex Ralfs, 1848 (Fig. 2, 7-8) - Loc.: 9c, 10c. Dim.: 574.6$624.3 \mu \mathrm{m}$ length and 51.9-52.2 $\mu \mathrm{m}$ wide.
Closterium venus Kützing ex Ralfs, 1848 (Fig. 2, 9) - Loc.: 10s. Dim.: 88.8-99.2 $\mu$ m length and 10.6-11.5 $\mu \mathrm{m}$ wide.

Family: Desmidiaceae Ralfs, 1848

COSMARIUM CONTRACTUM O.Kirchner, 1878 (Fig. 3, 10) - Loc.: 13c. Dim.: 21.8-28.4 $\mu$ m length and 17.3-20.4 $\mu \mathrm{m}$ wide. Isthmus 6.6-8.2 $\mu \mathrm{m}$ wide.

Cosmarium Depressum (Nägeli) P.Lundell, 1871 (Fig. 3, 11) - Loc.: 10c. Dim.: 36,9-41,9 $\mu \mathrm{m}$ length and 36,9-44,4 $\mu \mathrm{m}$ wide. Isthmus 10.3-11.6 $\mu \mathrm{m}$ wide.

${ }^{*}$ Cosmarium fontigenum Nordstedt, 1878 (Fig. 3, 12) - Loc.: 10s. Dim.: $25.9 \mu \mathrm{m}$ length and $26.6 \mu \mathrm{m}$ wide. Isthmus $8.4 \mu \mathrm{m}$ wide. 

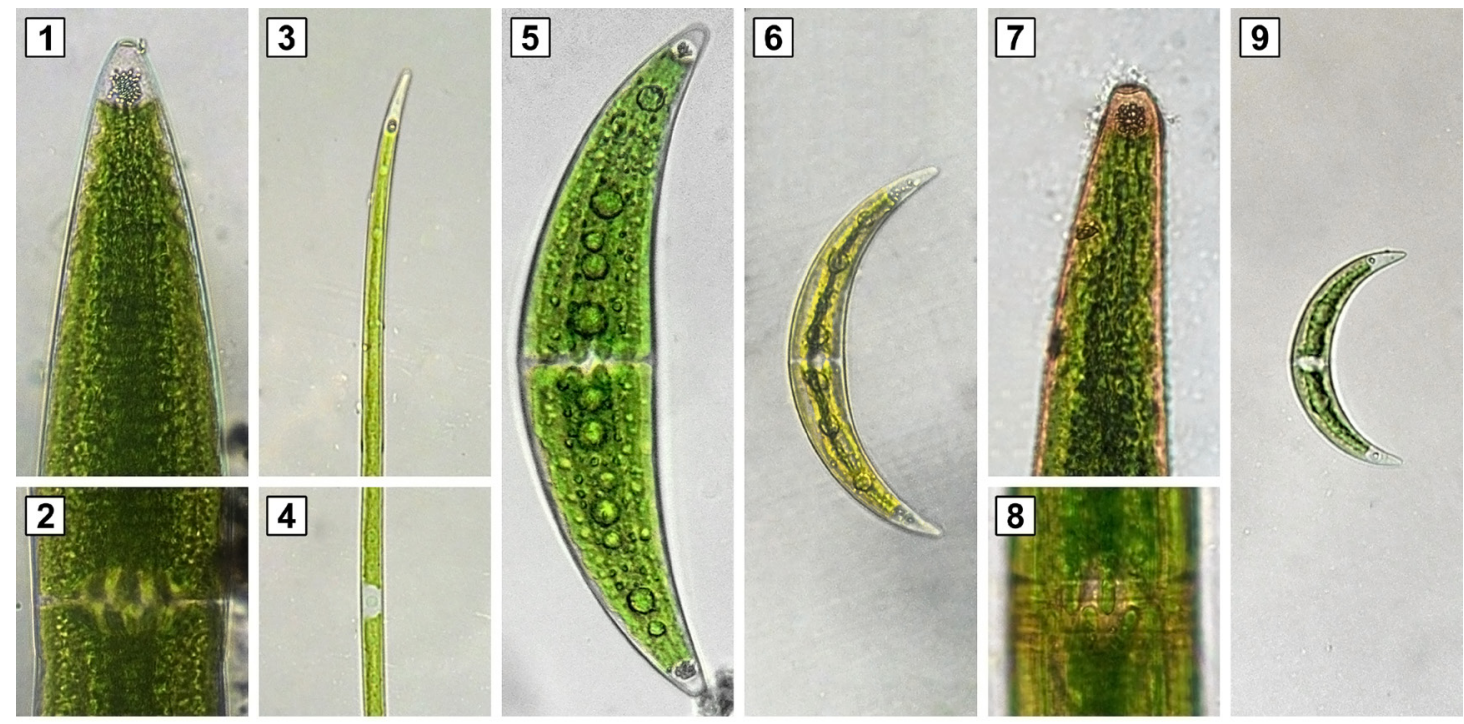

$50 \mu \mathrm{m}$

Fig. 2. 1-2 - Closterium acerosum, 3-4 - Closterium limneticum, 5 - Closterium moniliferum, 6 Closterium parvulum, 7-8-Closterium turgidum, 9 - Closterium venus.

COSMARIUM FORMOSUlum Hoff, 1888 (Fig. 3, 13) - Loc.: 10c. Dim.: 54.7-67.9 $\mu$ m length and 52.6-55.9 $\mu \mathrm{m}$ wide. Isthmus $16.5-19.4 \mu \mathrm{m}$ wide.

COSMARIUM GRANATUM Brébisson ex Ralfs, 1848 (Fig. 3, 14) - Loc.: 2s. Dim.: $42.8 \mu \mathrm{m}$ length and $29.3 \mu \mathrm{m}$ wide. Isthmus $11.1 \mu \mathrm{m}$ wide.

*Cosmarium ImPRESSUlum Elfving, 1881 (Fig. 1, 15) - Loc.: 7c, 9s, 17r. Dim.: 27.7-29.1 $\mu \mathrm{m}$ length and 19.1-21.7 $\mu \mathrm{m}$ wide. Isthmus 6.7-7.1 $\mu \mathrm{m}$ wide.

*Cosmarium Pachydermum P.Lundell, 1871 (Fig. 3, 16) - Loc.: 4c, 21c. Dim.: 71.4-79.6 $\mu \mathrm{m}$ length and 67.5-73.2 $\mu \mathrm{m}$ wide. Isthmus 36-44.9 $\mu \mathrm{m}$ wide.

${ }^{*}$ Cosmarium RegnelliI Wille, 1884 (Fig. 3, 17) Loc.: 10c, 11r. Dim.: 14.6-15.6 $\mu \mathrm{m}$ length and 12.8-14.7 $\mu \mathrm{m}$ wide. Isthmus $5.2-5.8$ $\mu \mathrm{m}$ wide.

COSMARIUM SUBPROTUMIDUM var. SEPTENTRIONALE (Croasdale) Coesel, 1989 (Fig. 3, 18) - Loc.: 7r, 10r, 11r. Dim.: 24.1-29.8 $\mu \mathrm{m}$ length and 21.7-26.9 $\mu \mathrm{m}$ wide. Isthmus $8.8-9.3$ $\mu \mathrm{m}$ wide.

*Desmidium aptogonum Brébisson ex Kützing, 1849 (Fig. 3, 19) - Loc.: 10r, 11s. Dim.: 16.8-17.6 $\mu \mathrm{m}$ length and 31.7-31.9 $\mu \mathrm{m}$ wide. Isthmus 25.8-26.1 $\mu$ m wide.

*Euastrum coeseli Kouwets, 1987 (Fig. 3, 20)
- Loc.: 10s. Dim.: $18.2 \mu$ m length and 15.1 $\mu \mathrm{m}$ wide. Isthmus $5.4 \mu \mathrm{m}$ wide.

EuASTRUM PULCHELLUM Brébisson, 1856 (Fig. 3, 21) - Loc.: 10c, 11s. Dim.: 24.3-28.8 $\mu \mathrm{m}$ length and 19-22.8 $\mu \mathrm{m}$ wide. Isthmus 7.4-7.9 $\mu \mathrm{m}$ wide.

HyalotheCA Dissiliens Brébisson ex Ralfs, 1848 (Fig. 3, 22) - Loc.: 9r, 10c. Dim.: 27.8-30.1 $\mu \mathrm{m}$ length and $13.3-18.3 \mu \mathrm{m}$ wide.

MiCRASTERIAS CRUX-MELITENSIS (Ehrenberg) Trevisan, 1842 (Fig. 3, 23) - Loc.: 9r, 10r. Dim.: 119.4-125.3 $\mu \mathrm{m}$ length and 113.1-121.3 $\mu \mathrm{m}$ wide. Isthmus 16.6-21.1 $\mu \mathrm{m}$ wide.

*Onychonema FILIForme (Ralfs) J.Roy et Bisset, 1886 (Fig. 3, 24) - Loc.: 9s. Dim.: 14.7-14.9 $\mu \mathrm{m}$ length and 16.4-17.6 $\mu \mathrm{m}$ wide. Isthmus 4.9-5.2 $\mu \mathrm{m}$ wide.

Pleurotaenium trabecula Nägeli, 1849 (Fig. 4, 25) - Loc.: 9c, 10c, 21r. Dim.: 451.6-612.5 $\mu \mathrm{m}$ length and 31.1-42.5 $\mu \mathrm{m}$ wide. Isthmus 3.5-3.7 $\mu \mathrm{m}$ wide.

*StauRastrum acutum Brébisson, 1856 (Fig. 4, 26) - Loc.: 10s. Dim.: $41.4 \mu \mathrm{m}$ length and $41.5 \mu \mathrm{m}$ wide. Isthmus $19.2 \mu \mathrm{m}$ wide.

Staurastrum aVicula Brébisson, 1848 (Fig. 4, 27) - Loc.: 13s. Dim.: $28.9 \mu \mathrm{m}$ length and $24.6 \mu \mathrm{m}$ wide without spines (with spines $29.7 \mu \mathrm{m}$ length and $36.1 \mu \mathrm{m}$ wide). Isthmus $9.2 \mu \mathrm{m}$ wide. 

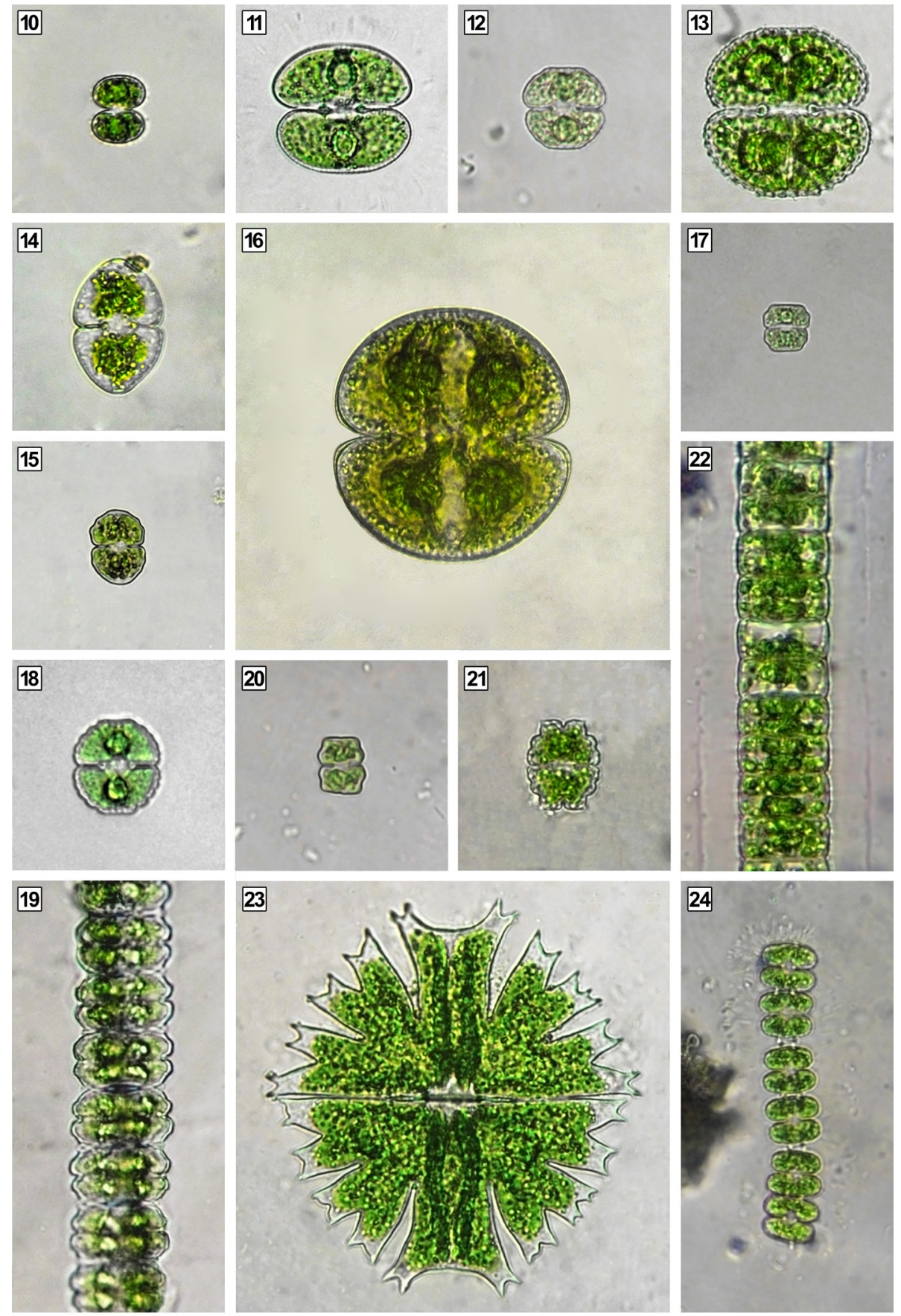

$50 \mu \mathrm{m}$

Fig. 3. 10 - Cosmarium contractum, 11 - Cosmarium depressum, 12 - Cosmarium fontigenum, 13 Cosmarium formosulum, 14-Cosmarium granatum, 15-Cosmarium impressulum, 16-Cosmarium pachydermum, 17 - Cosmarium regnellii, 18 - Cosmarium subprotumidum var. septentrionale, 19 - Desmidium aptogonum, 20 - Euastrum coeselii, 21 - Euastrum pulchellum, 22 - Hyalotheca dissiliens, 23 - Micrasterias crux-melitensis, 24 - Onychonema filiforme. 

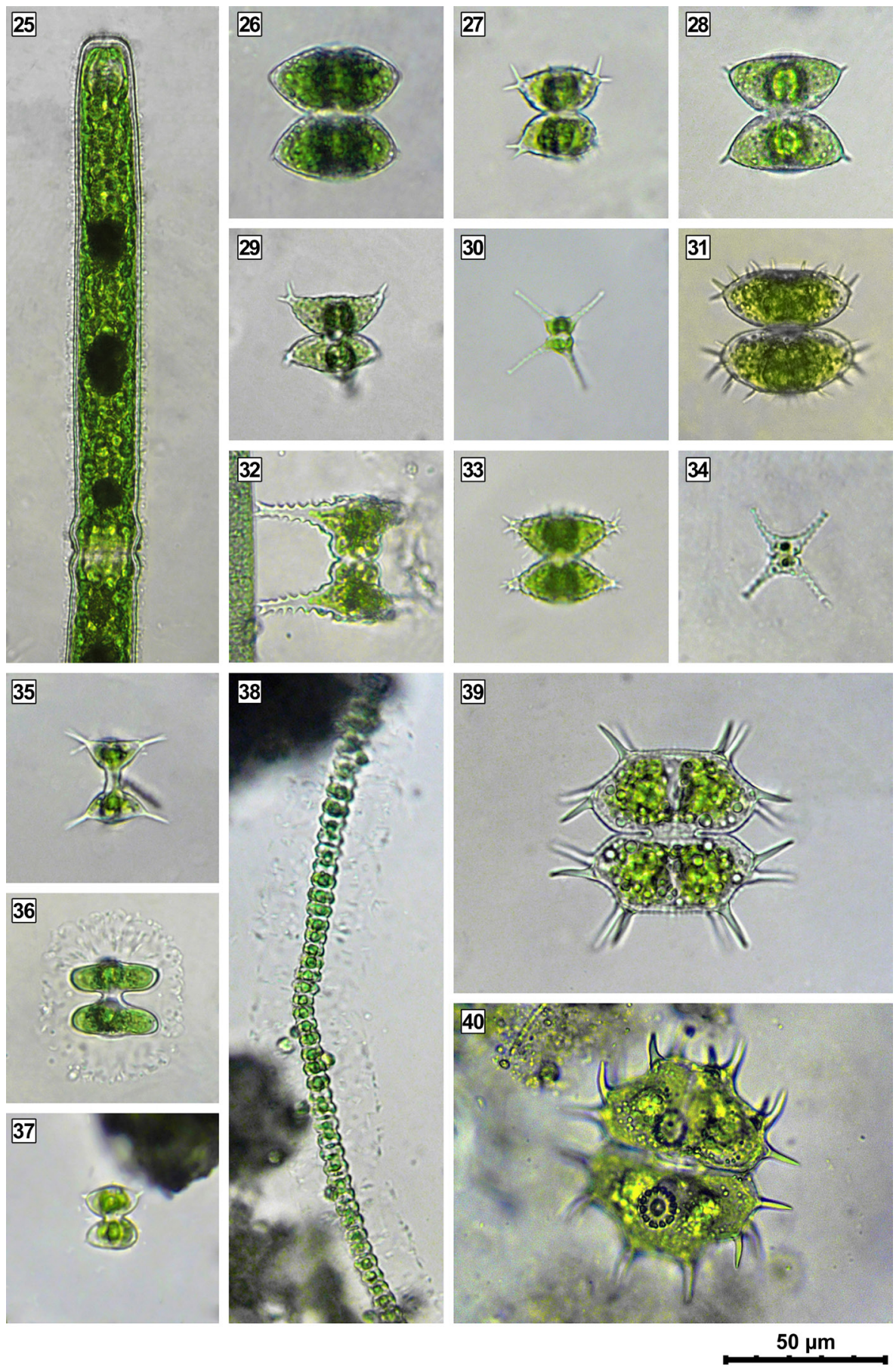

Fig. 4. 25 - Pleurotaenium trabecula, 26 - Staurastrum acutum, 27 - Staurastrum avicula, 28 Staurastrum avicula var. lunatum, 29 - Staurastrum avicula var. subarcuatum, 30 - Staurastrum chaetoceras, 31 - Staurastrum gladiosum, 32 - Staurastrum manfeldtii, 33 - Staurastrum polymorphum, 34 - Staurastrum tetracerum, 35 - Staurodesmus cuspidatus, 36 - Staurodesmus dejectus var. apiculatus, 37 - Staurodesmus patens, 38 - Teilingia excavata, 39 - Xanthidium antilopaeum, 40 - Xanthidium uncinatum. 
*Staurastrum avicula var. Lunatum (Ralfs) Coesel et Meesters, 2013 (Fig. 4, 28) - Loc.: 10r. Dim.: 36.1-38.8 $\mu \mathrm{m}$ length and 33.8-35.1 $\mu \mathrm{m}$ wide without spines (with spines 40-41.9 $\mu \mathrm{m}$ wide). Isthmus $13.1-13.6 \mu \mathrm{m}$ wide.

*STAURASTRUm aVicula var. SUbarcuatum (Wolle) West et G.S.West 1894 (Fig. 4, 29) - Loc.: 10s. Dim.: $23.3 \mu \mathrm{m}$ length and $29.9 \mu \mathrm{m}$ wide without processes. Isthmus $9.9 \mu \mathrm{m}$ wide.

*STAURASTRUM CHAETOCERAS (Schröder) G.M.Smith, 1924 (Fig. 4, 30) - Loc.: 5r, 11a, 13r. Dim.: $12.9 \mu \mathrm{m}-21.6$ length and $10.1-13.7 \mu \mathrm{m}$ wide without processes (with processes 27.5-39.3 $\mu \mathrm{m}$ length and 38.4-48.3 $\mu \mathrm{m}$ wide). Isthmus 6.9-8.3 $\mu \mathrm{m}$ wide.

*STAuRastrum gladiosum W.B.Turner, 1885 (Fig. 4, 31) - Loc.: 21s. Dim.: $38.8 \mu \mathrm{m}$ length and $41.5 \mu \mathrm{m}$ wide without spines (with spines $43.2 \mu \mathrm{m}$ length and $50.1 \mu \mathrm{m}$ wide). Isthmus $15.5 \mu \mathrm{m}$ wide.

STAuRASTRUM MANFELdTi Delponte, 1878 (Fig. 4, 32) - Loc.: 7r, 9c, 11r. Dim.: 39.2-52.4 $\mu \mathrm{m}$ length and 24,9-26.4 $\mu \mathrm{m}$ wide without processes (with processes 63.1-70.1 $\mu$ m wide). Isthmus $10.3-13.6 \mu \mathrm{m}$ wide.

STAURASTRUM POLYMORPHUM Brébisson, 1848 (Fig. 4, 33) - Loc.: 13r. Dim.: 26.1-27.3 $\mu$ m length and 32.2-32.5 $\mu \mathrm{m}$ wide. Isthmus 9.8-10.1 $\mu \mathrm{m}$ wide.

*STaurastrum tetracerum Ralfs ex Ralfs, 1848 (Fig. 4, 34) - Loc.: 9r. Dim.: $12 \mu$ m length and $12.1 \mu \mathrm{m}$ wide without processes (with processes $29.3 \mu \mathrm{m}$ length and $27.5 \mu \mathrm{m}$ wide). Isthmus $6.1 \mu \mathrm{m}$ wide.

Staurodesmus cuspidatus (Brébisson) Teiling, 1967 (Fig. 4, 35) - Loc.: 13r. Dim.: 25.3-26.3 $\mu \mathrm{m}$ length and 18.9-19.1 $\mu \mathrm{m}$ wide without spines (with spines 26.9-29.7 $\mu \mathrm{m}$ length and 32.9-33.3 $\mu \mathrm{m}$ wide). Isthmus 4.5-5.5 $\mu \mathrm{m}$ wide.

*STAUROdESMUS DEJECTUS var. APICULATUS (Brébisson) Croasdale, 1957 (Fig. 4, 36) - Loc.: 9c, 21r. Dim.: 20.3-23.9 $\mu \mathrm{m}$ length and 22.7-27.7 $\mu \mathrm{m}$ wide. Isthmus 5.6-6 $\mu \mathrm{m}$ wide.

*STaurodesmus patens (Nordstedt) Croasdale, 1957 (Fig. 4, 37) - Loc.: 13s. Dim.: $20.4 \mu \mathrm{m}$ length and $16.4 \mu \mathrm{m}$ wide without spines (with spines $20.3 \mu \mathrm{m}$ wide). Isthmus 6.6 $\mu \mathrm{m}$ wide.

*Teilingia excavata (Ralfs ex Ralfs) Bourrelly, 1964 (Fig. 4, 38) - Loc.: 10s. Dim.: 7.8-9.8 $\mu \mathrm{m}$ length and $6.8-8.8 \mu \mathrm{m}$ wide. Isthmus 5.2-5.4 $\mu \mathrm{m}$ wide.
Xanthidium antilopaeum Kützing, 1849 (Fig. 4, 39) - Loc.: 10c. Dim.: 50.9-52.5 $\mu$ m length and 51.4-53.8 $\mu \mathrm{m}$ wide without spines (with spines 65.9-70.6 $\mu \mathrm{m}$ length and 70.9-75.2 $\mu \mathrm{m}$ wide). Isthmus $14.9-17 \mu \mathrm{m}$ wide.

Xanthidium Uncinatum (Ralfs) Stastny, Skaloud et Neustupa, 2013 (Fig. 4, 40) - Loc.: 10c. Dim.: 61.4-64.3 $\mu \mathrm{m}$ length and 55.5-61.1 $\mu \mathrm{m}$ wide without spines (with spines 82.1-85.4 $\mu \mathrm{m}$ length and $77-83.1 \mu \mathrm{m}$ wide). Isthmus 16.9-19.7 $\mu \mathrm{m}$ wide.

\section{DISCUSSION}

Thirty-seven species and infraspecific taxa which belong to 12 genera and 2 families were identified. The majority of species belong to genera Cosmarium (24.3\%), Staurastrum (24.3\%) and Closterium (16.2\%), whereas others constitute $35 \%$ of the total species diversity.

Despite the relative poverty of the species composition, 17 species identified are new to the eastern macroslope of the Middle Urals. Nevertheless, this fact rather points to gaps in the knowledge of the studied area, given that most of the studied species are common in other areas of the Ural ridge (Briškaitè et al., 2016; Snitko \& Sergeeva, 2003; Patova \& Demina, 2008; Sterlyagova, 2008; Snitko, 2009; Voronikhin, 1930; Yarushina et al, 2004). However, particular attention deserves a finding of Euastrum coeselii, a rare species for the territory of Russia, which has been recorded only once in the Moscow region (Anissimova, 2015).

Canonical correspondence analysis, which based on species composition of water bodies as a dependent variable and types of water bodies as an explanatory variable, was performed to reveal habitat preferences of algal species as it has been previously made by Kaštovsky et al (2011). Ordination diagram (pseudo- $\mathrm{F}=1.6, \mathrm{p}=0.01$ ) (Fig. 5) demonstrates that the majority of species $(89 \%)$ were associated with ponds and quarry lakes, i.e. typically mesotrophic water bodies with submerged aquatic vegetation, which agrees with the previous data (Kosinskaya, 1960; Coesel \& Meesters, 2007). Small group of mesotrophic (Staurastrum polymorphum) and oligo-mesotrophic species (eg. Cosmarium contractum, Staurodesmus cuspidatus), however, were found in a phytoplankton of rivers, but 


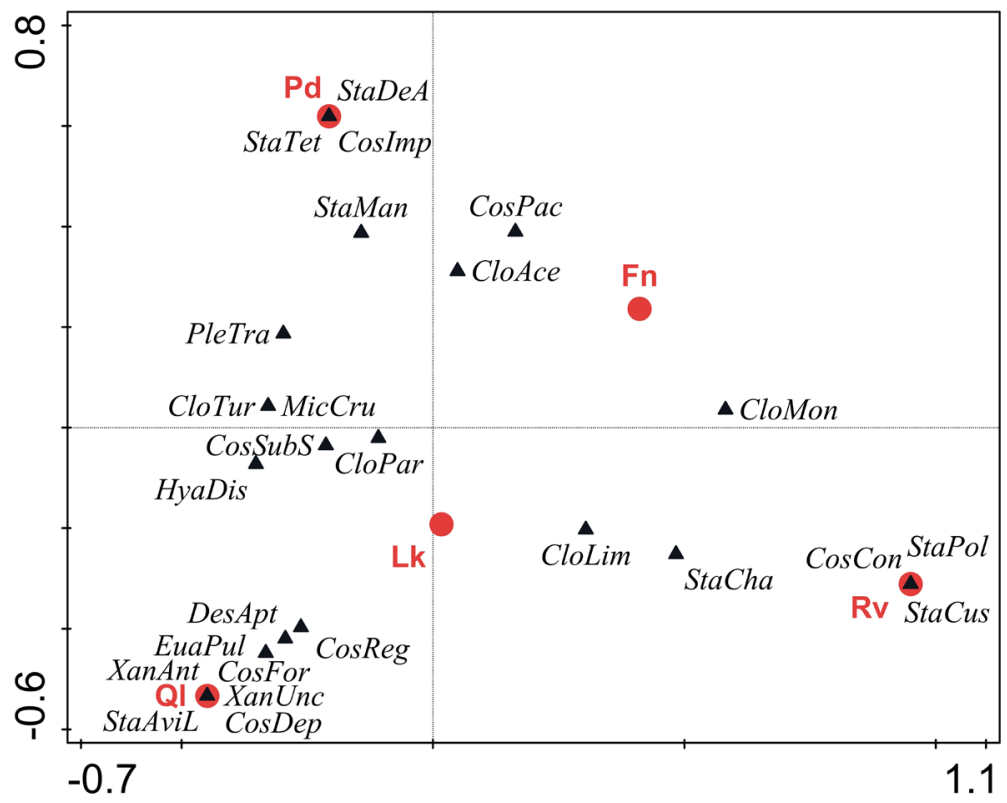

Fig. 5. CCA ordination plot showing the preferences of the most common desmid species to the water body type (Lk-lakes, Fn-fens, Q1-quarry lakes, Pd-ponds, Rv-rivers). Abbreviations of species names include the first three letters of a genus and a species names, and one letter of a variation name.

they could be overlooked because of their low abundance. On the contrary to them, eutrophic species (e.g. Closterium acerosum, C. limneticum, Staurastrum chaetoceras) that constitute together with the oligo-eutrophic Staurastrum tetracerum a minority (11\%), do not show particular preferences, since they were found in all types of water bodies. This fact can be explained by a high local anthropogenic eutrophication.

\section{ACKNOWLEDGEMENTS}

We would like to express our gratitude to A. F. Lukinskaya (V.L. Komarov Botanical Institute RAS, St. Petersburg, Russia) for checking the species determination. We are also very grateful to the editor and anonymous reviewer for the improvement of the manuscript.

\section{REFERENCES}

Anissimova, O. V. 2015. New species of desmids (Conjugatophyceae, Charophyta) to the Algae flora of Moscow Region. Moscow Biological Science Bulletin 70(2): 78-81. https://doi.org/10.3103/ S0096392515020029

Briškaite, R., Patova, E. \& Juzènas, S. 2016. Desmid flora in the lakes of the Khrebtovyi Nature Reserve in the Polar Ural (Russia). Botanica Lithuanica 22(2): 113-122. https://doi.org/10.1515/botlit-2016-0012

Butakova, E. A. \& Stanislavskaya, E. V. 2004. Periphyton of the Iset river basin (Sverdlovsk region). Botanicheskiy Zhurnal89(9): 1420-1436. (In Russian).

Coesel, P. F. M. \& Meesters, K. J. 2007. Desmids of the lowlands. Zeist, KNNW Publishing. 351 pp. https://doi.org/10.1163/9789004277922

Coesel, P. F. M. \& Meesters, K. J. 2013. European flora of the desmid genera Staurastrum and Staurodesmus. Zeist, KNNV Publishing. 357 pp.

Guiry, M. D. \& Guiry, G. M. 1996-2018. AlgaeBase. World-wide electronic publication. Galway, National University of Ireland. http://www.algaebase. org (Accessed at 14 March 2018).

Kaštovsky, J., Fučikova, K., Hauer, T. \& Bohunicka, M. 2011. Microvegetation on the top of Mt. Roraima, Venezuela. Fottea 11(1): 171-186. https://doi. org/ 10.5507 / fot. 2011.017

Kosinskaya, E. K. 1960. Flora of cryptogamic plants of USSR. Conjugates. Desmids algae. 5 (2). MoscowLeningrad, USSR Academy of Sciences Publishing House. 511 pp. (In Russian).

Kulikov, P. V., Zolotaryova, N. V. \& Podgaevskaya, E. N. 2013. Endemic plants in Sverdlousk region flora. Ekaterinburg, Goshchitskii. 612 pp. (In Russian).

Palamar-Mordvintseva, G. M. 1982. The key to freshwater algae of the USSR. Conjugatophyceae. Desmidiales. 11 (2). Leningrad, Nauka. 620 pp. (In Russian). 
Patova, E. N. \& Demina, I. V. 2008. Algae in anthropogenically unaffected water bodies of the Polar Urals. Inland Water Biology 1(1): 54-63. https:// doi.org/10.1007/s12212-008-1009-y

Seleznev, A. A. \& Yarmoshenko, I. V. 2014. Study of urban puddle sediments for understanding heavy metal pollution in an urban environment. Environmental Technology \& Innovation 1-2: 1-7. https://doi.org/10.1016/j.eti.2014.08.001

Snitko, L. V. \& Sergeeva, R. M. 2003. Algae of different-type water bodies in the eastern part of the Southern Urals. Miass, Ilmen State Reserve. 166 pp. (In Russian).

Snitko, L. V. 2009. Ecology and successions of the phytoplankton in Southern Urals lakes. Miass, I1men State Reserve. 376 pp. (In Russian).
Sterlyagova, N. I. 2008. Desmids in mountain lakes of the subpolar Urals. Biologia 63(6): 911-916. https://doi.org/10.2478/s11756-008-0142-8

ter Braak, C. J. F. \& Šmilauer, P. 2012. Canoco Reference Manual and User's Guide: Software for Ordination (Version 5.0). Ithaca, Microcomputer Power. 496 pp.

Voronikhin, N. N. 1930. Algae of the Polar and the Northern Urals. Trudy Leningradskogo obshchestva estestvoispytatelei 60 (3): 3-80. (In Russian).

Yarushina, M.I., Tanaeva, G.V. \& Eremkina, T.V. 2004. Algal flora of the Chelyabinsk region water reservoirs. Ekaterinburg, IPAE. 308 pp. (In Russian). 
16 Folia Cryptog. Estonica 